\title{
Recent Progress and Novel Applications in Enzymatic Conversion of Carbon Dioxide
}

\author{
Nguyen Van Duc Long ${ }^{1,2}$, Jintae Lee ${ }^{2}$, Kee-Kahb Koo ${ }^{3}$, Patricia Luis ${ }^{4, *}$ and Moonyong Lee ${ }^{2, *}$ \\ 1 Department for Management of Science and Technology Development \& Faculty of Applied Sciences, \\ Ton Duc Thang University, Ho Chi Minh City, Vietnam; nguyenvanduclong@tdt.edu.vn \\ 2 School of Chemical Engineering, Yeungnam University, Gyeongsan 712-749, Korea; mynlee@yu.ac.kr \\ 3 Department of Chemical and Biomolecular Engineering, Sogang University, Seoul 04107, Korea; \\ koo@sogang.ac.kr \\ 4 Materials \& Process Engineering (iMMC-IMAP), Université catholique de Louvain, Place Sainte Barbe 2, \\ 1348 Louvain-la-Neuve, Belgium \\ * Correspondence: patricia.luis@uclouvain.be (P.L.); mynlee@yu.ac.kr (M.L.); \\ Tel.: +32-(0)10-472402 (P.L.); +82-53-810-2512 (M.L.)
}

Academic Editor: Fernando Rubiera González

Received: 4 March 2017; Accepted: 27 March 2017; Published: 3 April 2017

\begin{abstract}
Turning carbon dioxide $\left(\mathrm{CO}_{2}\right)$ into fuels and chemicals using chemical, photochemical, electrochemical, and enzymatic methods could be used to recycle large quantities of carbon. The enzymatic method, which is inspired by cellular $\mathrm{CO}_{2}$ metabolism, has attracted considerable attention for efficient $\mathrm{CO}_{2}$ conversion due to improved selectivity and yields under mild reaction conditions. In this review, the research progress of green and potent enzymatic conversion of $\mathrm{CO}_{2}$ into useful fuels and chemicals was discussed. Furthermore, applications of the enzymatic conversion of $\mathrm{CO}_{2}$ to assist in $\mathrm{CO}_{2}$ capture and sequestration were highlighted. A summary including the industrial applications, barriers, and some perspectives on the research and development of the enzymatic approach to convert $\mathrm{CO}_{2}$ were introduced.
\end{abstract}

Keywords: carbon dioxide $\left(\mathrm{CO}_{2}\right)$; enzymatic conversion of $\mathrm{CO}_{2} ; \mathrm{CO}_{2}$ utilization; $\mathrm{CO}_{2}$ capture; $\mathrm{CO}_{2}$ sequestration

\section{Introduction}

Global warming and climate change, referring to increased average global temperatures, have inspired a global effort to reduce the amount of atmospheric carbon dioxide $\left(\mathrm{CO}_{2}\right)$. Many approaches have been considered and adopted for reducing $\mathrm{CO}_{2}$ emissions, including enhancing energy efficiency and promoting energy conservation; increasing the usage of low carbon fuels, including natural gas, hydrogen, or nuclear power; deploying renewable energy sources such as solar, wind, hydropower, and bioenergy; applying geoengineering approaches such as afforestation and reforestation; $\mathrm{CO}_{2}$ capture and storage (CCS); and converting $\mathrm{CO}_{2}$ into fuels and chemicals [1]. Among these approaches, turning $\mathrm{CO}_{2}$ into fuels and chemicals offers a win-win strategy to both decrease atmospheric $\mathrm{CO}_{2}$ and efficiently exploit carbon resources [2].

From fundamental research to industrial applications, the efficient transformation of $\mathrm{CO}_{2}$ has attracted growing international interest. The concept behind the $\mathrm{CO}_{2}$ conversion to chemicals and fuels is attractive: the direct energy supply via combustion of carbonaceous energy carriers produces $\mathrm{CO}_{2}$, which could be converted back into the energy carrier, thereby resulting to an artificial carbon cycle that recycles $\mathrm{CO}_{2}$ and balances anthropogenic emissions [3,4]. To catalyze $\mathrm{CO}_{2}$ conversion, chemical, photochemical, electrochemical, and enzymatic methods have been employed. In the first three methods, high operating temperature and pressure or additional electric or luminous energy are 
required, and some selectivity and yield issues accompany these methods [5]. Meanwhile, occurring under mild reaction conditions with high yields and selectivity and without any side effect on the environment, the enzymatic conversion of $\mathrm{CO}_{2}$ has comparative benefits [5-7].

Interestingly, the enzymatic conversion of $\mathrm{CO}_{2}$ can be applied not only for efficient $\mathrm{CO}_{2}$ utilization [7], but also for assisting $\mathrm{CO}_{2}$ capture [8], the process of capturing waste $\mathrm{CO}_{2}$ from fossil fuel power plant flue gas using absorption or membrane technologies, and $\mathrm{CO}_{2}$ sequestration [9], the capture and long-term storage of atmospheric $\mathrm{CO}_{2}$. Although these promising concepts have been applied in industry, their application is still in the interim period between the research stage and the application stage, in addition to other barriers. Thus, in this paper, we review recent developments in the enzymatic conversion of $\mathrm{CO}_{2}$ in vitro, which mimics cellular $\mathrm{CO}_{2}$ metabolic processes. Applications of the enzymatic conversion of $\mathrm{CO}_{2}$ to assist $\mathrm{CO}_{2}$ capture and sequestration are highlighted. Industrial applications, barriers, and some perspectives on the research and development of the enzymatic conversion of $\mathrm{CO}_{2}$ are also discussed.

\section{Natural Conversion of $\mathrm{CO}_{2}$ in Cells}

The fixation of inorganic carbon into organic material (chemoautotrophy) is a prerequisite for life and represents the starting point of biological evolution [10]. Biological fixation, an essential factor in controlling atmospheric $\mathrm{CO}_{2}$ concentrations, can occur through six major pathways including the Calvin-Benson-Bassham cycle, the reductive citric acid cycle, the reductive acetyl-CoA pathway, the 3-hydroxypropionate/malyl-CoA cycle, the 3-hydroxypropionate/4-hydroxybutyrate cycle, and the dicarboxylate/4-hydroxybutyrate cycle [11]. They impact substantially to the global carbon cycle, in which enzymes play crucial roles in catalyzing the $\mathrm{CO}_{2}$ fixation [12]. Beside, a large number of enzymes, such as decarboxylase enzymes in carboxylation reactions derived from catabolic pathways, utilize $\mathrm{CO}_{2}$ or $\mathrm{HCO}_{3}{ }^{-}$as a reaction substrate and do not belong to chemoautotrophic pathways $[2,12,13]$.

Generally, such $\mathrm{CO}_{2}$ transformation processes are coupled with oxidation processes that generate reducing equivalents, sometimes conjunctive with the hydrolysis of phosphoanhydride bonds [12,14-16]. Adenosine triphosphate (ATP) and nicotinamide adenine dinucleotide hydride (NADH) or their equivalents are required in all known natural $\mathrm{CO}_{2}$ conversion pathways [12,15]. Various pathways for the conversion of $\mathrm{CO}_{2}$ associated to the dependence of chemoautotrophic organisms on $\mathrm{CO}_{2}$ have been developed (Figure 1) [10,12]. These enzymatic conversions of $\mathrm{CO}_{2}$ and carboxylation reactions derived from catabolic pathways are considered fundamental to science and have inspired in vitro studies and industrial applications.

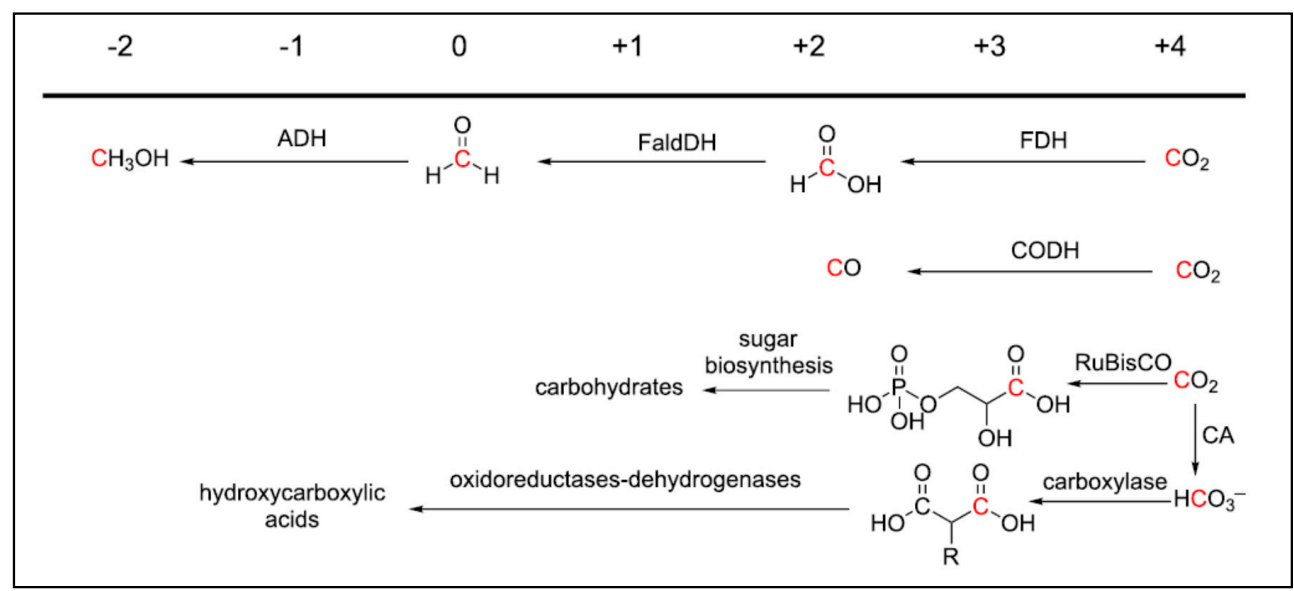

Figure 1. Biocatalytic routes for the conversion of $\mathrm{CO}_{2}$ into compounds with carbon in the reduced oxidation states indicated at the top. FDH: formate dehydrogenase, FaldDH: formaldehyde dehydrogenase, $\mathrm{ADH}$ : alcohol dehydrogenase, $\mathrm{CODH}$ : carbon monoxide dehydrogenase, RuBisCO: ribulose-1,5-bisphosphate carboxylase oxygenase, CA: carbonic anhydrase, $\mathrm{R}: \mathrm{H}, \mathrm{CH}_{3}$ [12]. 


\section{Enzymatic Conversion of $\mathrm{CO}_{2}$ In Vitro}

A tremendous amount of effort has been dedicated to constructing $\mathrm{CO}_{2}$ conversion systems in vitro inspired by cellular $\mathrm{CO}_{2}$ metabolic processes. These processes can consist of a single enzyme, using oxidoreductases or lyases, or of multiple enzymes such as multiple dehydrogenases in methanol production.

\subsection{Reduction Reactions}

\subsubsection{Conversion of $\mathrm{CO}_{2}$ to Carbon Monoxide}

Converting $\mathrm{CO}_{2}$ to carbon monoxide (CO), the feedstock for various synthetic processes, through the production of hydrocarbons (Fischer-Tropsch process), acetic acid (Monsanto and Cativa processes), and methanol catalyzed by carbon monoxide dehydrogenases (CODHs) has received much attention [17-19]. There are two types of $\mathrm{CODHs}$ including the $\mathrm{O}_{2}$-sensitive enzymes from obligate anaerobes containing $\left[\mathrm{Fe}_{4} \mathrm{~S}_{4} \mathrm{Ni}\right]$ and air-stable enzymes with [MoSCu] active sites [20]. The [NiFe] CODHs result turnover frequencies for $\mathrm{CO}$ oxidation as high as $40,000 \mathrm{~s}^{-1}$ and $45 \mathrm{~s}^{-1}$ for $\mathrm{CO}_{2}$ reduction, while the $[\mathrm{MoCu}] \mathrm{CODHs}$ do not catalyze the reduction of $\mathrm{CO}_{2}$ to $\mathrm{CO}[19,20]$. The conversion of $\mathrm{CO}_{2}$ to $\mathrm{CO}$ is accomplished using [NiFe] $\mathrm{CO}$ dehydrogenases with the proposed mechanism presented in Scheme 1 [20].

Shin et al. (2003) [21] first found that CODH is a suitable catalyst for electrochemical CO2 reduction, exhibiting almost no overpotential. Woolerton et al. [17,22] discovered an innovative efficient technique that combines photocatalysis efficiently and cleanly in the enzymatic conversion of $\mathrm{CO}_{2}$ to $\mathrm{CO}$. Figure 2 shows the hybrid system comprising metal oxide nanoparticles functionalized with the enzyme $\mathrm{CODH}$, and sensitized to visible light using a ruthenium bipyridyl photosensitizer [22]. Of the semiconductor materials that they investigated, photocatalysts prepared with Evonik Degussa P25 $\mathrm{TiO}_{2}$ (a commercially available 3:1 mixture of anatase/rutile) and ordinary anatase $\mathrm{TiO}_{2}$ nanoparticles were found to be the most effective, in terms of overall turnover rate.

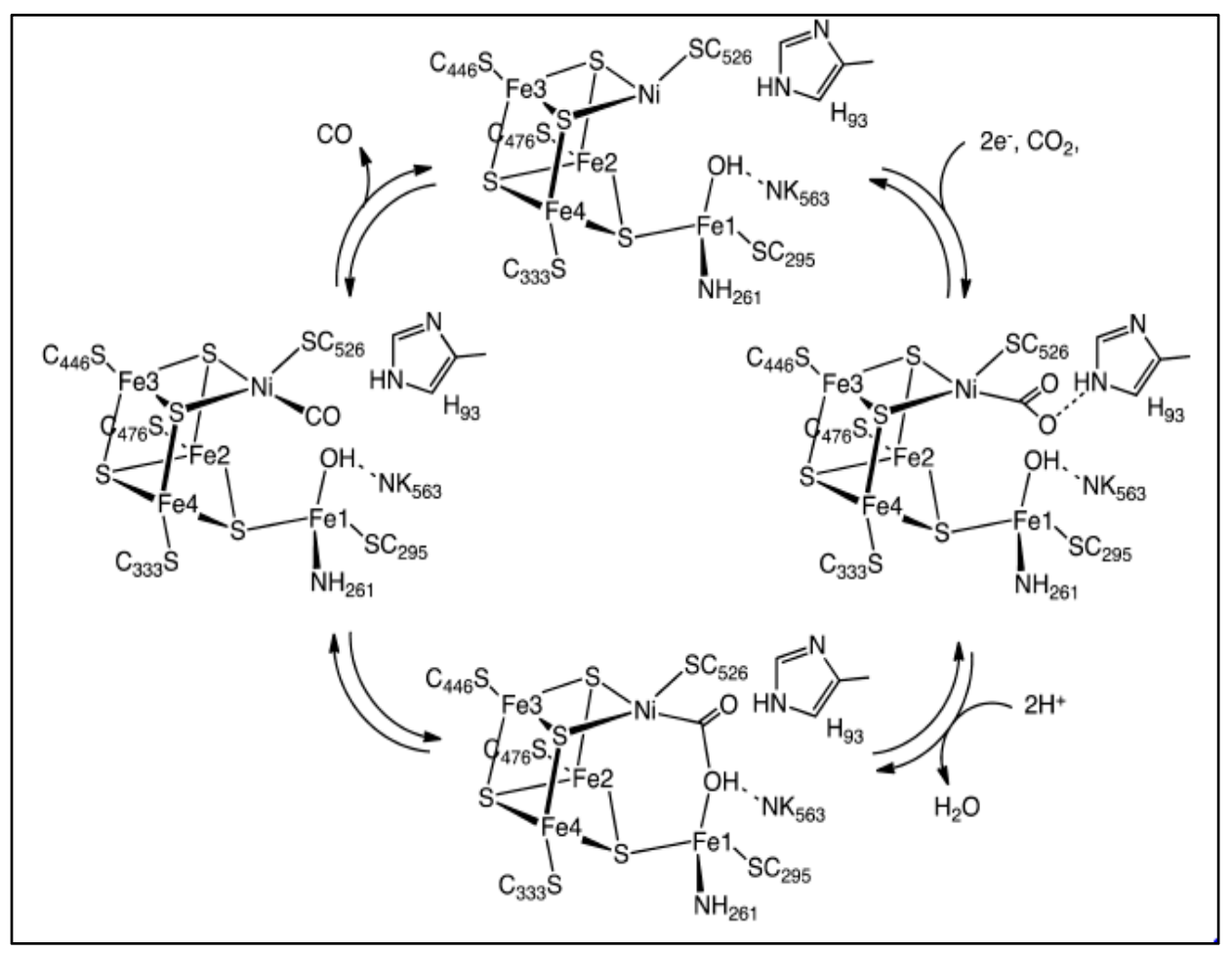

Scheme 1. Proposed mechanism for the reduction of $\mathrm{CO}_{2}$ to $\mathrm{CO}$ by [NiFe] CODH [20]. 


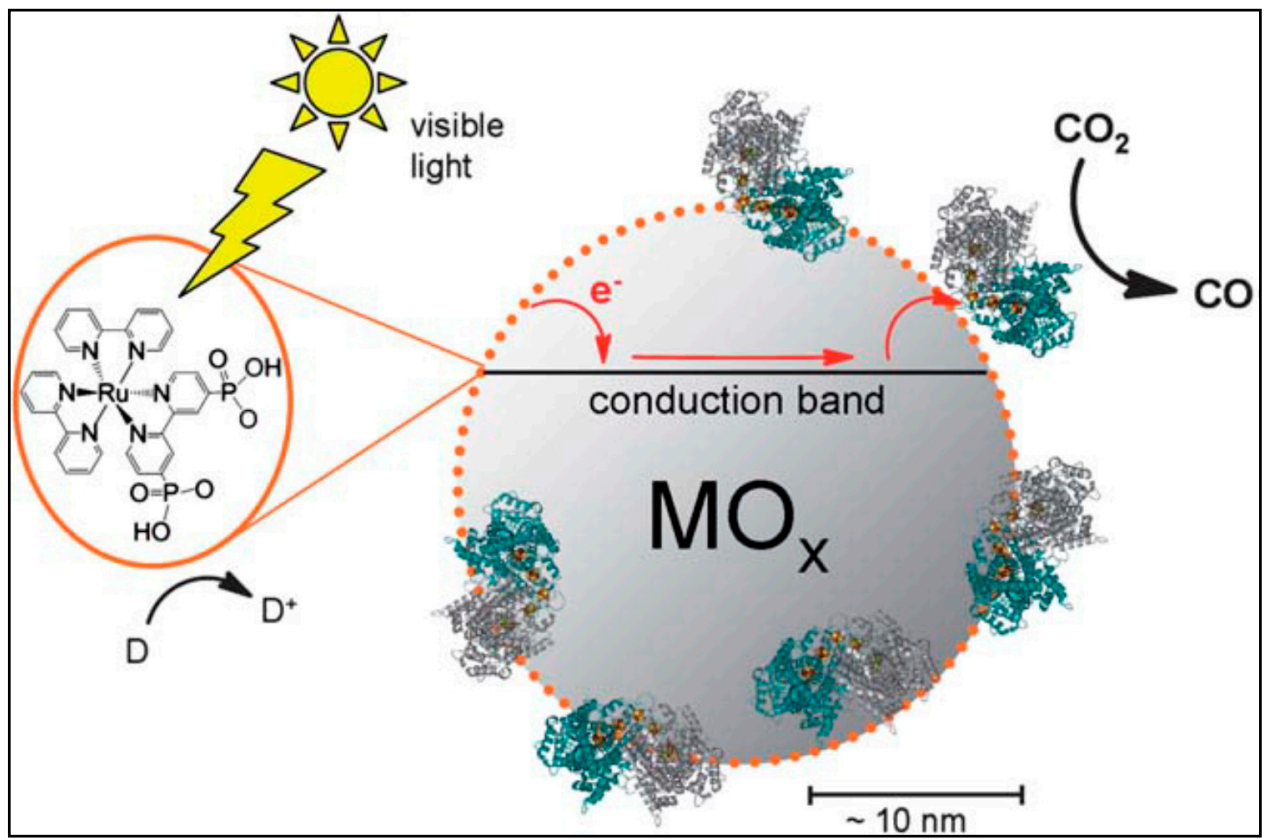

Figure 2. Cartoon representation of $\mathrm{CO}_{2}$ reduction at an enzyme-modified metal oxide nanoparticle, sensitized with a ruthenium dye. D represents a sacrificial electron donor, used to regenerate the dye following photoinjection into $\mathrm{MO}_{x}$. Dimensions of each species are approximately to scale for when $\mathrm{MO}_{x}$ is a Degussa P25 anatase $\mathrm{TiO}_{2}$ nanoparticle [22].

More recently, Bachmeier et al. [23] demonstrated that semiconducting electrodes can be used to impose directionality on reversible catalysts operating in the region of the flatband potential. Although these enzymes are unsuited for long-term, large-scale systems, their results provide valuable insight for developing integrated artificial systems (based ultimately on abundant chemical catalysts) [23].

\subsubsection{Conversion of $\mathrm{CO}_{2}$ to Formic Acid/Formate}

Formic acid/formate, which can be used for silage preservation, animal feed additives, textile finishing, and chemical intermediates [24], as one of the most promising candidate fuels for low-temperature fuel cells [25], and in paper and pulp production, is one of main products from the enzymatic conversion of $\mathrm{CO}_{2}$ [26]. The formate oxidation to $\mathrm{CO}_{2}$ occurs with the concomitant $\mathrm{NAD}^{+}$ reduction to $\mathrm{NADH}$ catalyzed by formate dehydrogenase ( $\mathrm{FDH}$ or $\mathrm{F}_{\text {ate }} \mathrm{DH}$ ) [27]. Interestingly, the reverse reaction, the reduction of $\mathrm{CO}_{2}$ to formate, can be catalyzed by the same enzyme [28,29]. FDH from Pseudomonas oxalaticus has been used to reduce $\mathrm{CO}_{2}$ into formate using oxidized methyl viologen as an electron relay [30]. The tungsten-containing FDH from Syntrophobacter fumaroxidans, known to be the most active catalyst for the reaction so far, has also been used to reduce $\mathrm{CO}_{2}$ to formate [31].

To generate NADH, novel graphene-based visible light active photocatalyst which covalently bonded the chromophore, such as multianthraquinone substituted porphyrin with the chemically converted graphene as a photocatalyst of the artificial photosynthesis system was reported [32]. The rhodium complex shuttles as an electron mediator between the graphene photocatalyst and $\mathrm{NAD}^{+}$, proving to be an efficient factor for regeneration of the NADH cofactor. Recently, a photocatalyst-biocatalyst coupled system developed using graphene-based visible light active photocatalyst in a highly efficient manner, leading to high NADH regeneration $(54.02 \% \pm 0.61 \%)$, followed by its consumption in exclusive formic acid production $(144.2 \pm 1.8 \mu \mathrm{mol})$ from $\mathrm{CO}_{2}$ [33].

Because the NADH-independent FDH enzymes are highly unstable and inactive in the presence of $\mathrm{O}_{2}$, Kim et al. [34] focused on the NADH-dependent FDH from Candida boidinii (CbsFDH), which was sufficiently stable for commercial use, and found that almost $100 \%$ selectivity can be achieved for 
formate formation from $\mathrm{CO}_{2}$ in recent study (as shown in Scheme 2). The reaction rate can be increased only within the optimized reaction conditions of electrochemical NADH regeneration. Therefore, a robust new FDH that operates in high NADH and enzyme concentrations should be identified or developed for an electroenzymatic method to convert $\mathrm{CO}_{2}$ into formate on a preparative scale.

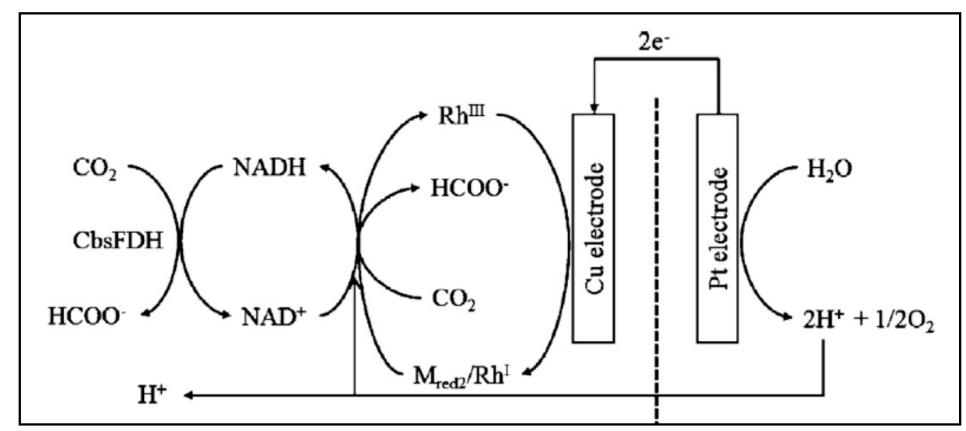

Scheme 2. Schematic diagram of electroenzymatic $\mathrm{CO}_{2}$ reduction using $\mathrm{CbsFDH}$ [34].

\subsubsection{Conversion of $\mathrm{CO}_{2}$ to Methanol}

Methanol, a fuel and key starting material for many important industrial applications, can be produced from $\mathrm{CO}_{2}$ reduction. Obert and Dave [7] reported an enzymatically coupled sequential reduction of carbon dioxide to methanol using three different dehydrogenases including FDH, formaldehyde dehydrogenase $\left(\mathrm{F}_{\text {ald }} \mathrm{DH}\right)$, and alcohol dehydrogenase $(\mathrm{ADH})$. The overall reaction process, in which terminal electron donor in each dehydrogenase-catalyzed reduction is reduced $\mathrm{NADH}$, is shown in Figure 3 [35].

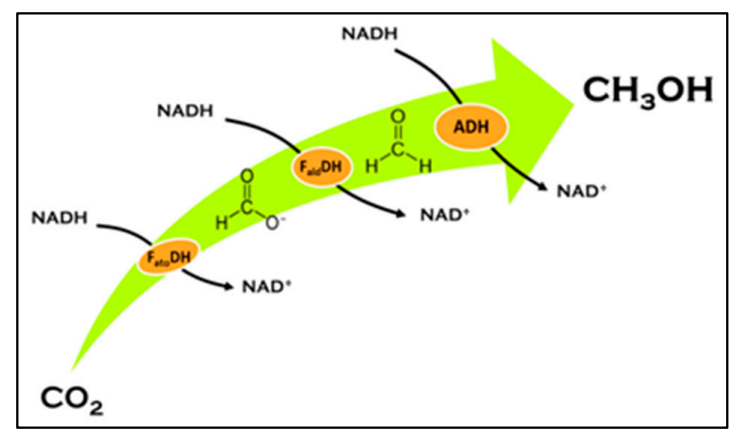

Figure 3. $\mathrm{CO}_{2}$ reduction to methanol in water promoted by $\mathrm{F}_{\text {ate }} \mathrm{DH}, \mathrm{F}_{\mathrm{ald}} \mathrm{DH}$, and $\mathrm{ADH}$ where three consecutive $2 \mathrm{e}^{-}$steps are involved [35].

However, this process still has several problems such as cosolvents and catalysts are in the sol-gel process due to low water solubility and reactivity of the silica precursor, and the alcohol liberated from hydrolysis, cosolvents, and catalysts are deleterious to bioactivity [36]. To overcome these problems, several modifications to the sol-gel technique were proposed to improve the stability of the biological activity [36-40]. The dehydrogenases encapsulated in the alginate-silicate composite showed high initial enzyme activity retention, and significantly improved stability during storage and reuse [36]. These enzymes can be also immobilized in flat-sheet polymeric membranes simultaneously or separately by simple pressure-driven filtration (i.e., by directing membrane fouling formation), without any addition of organic solvent [41]. As a result, enzyme activity was fully retained by this non-covalent immobilization strategy.

Three moles of NADH is required to produce one mole of $\mathrm{CH}_{3} \mathrm{OH}$ from $\mathrm{CO}_{2}$ (Figure 3), therefore, NADH regeneration is necessary [35]. To provide the possibility for practical application, a hybrid enzymatic/photocatalytic approach for efficient converting $\mathrm{CO}_{2}$ into methanol was recently 
proposed [35]. The proposed approach includes two processes: the enzymatic transformation of $\mathrm{CO}_{2}$ to methanol promoted by NADH, and the in situ photocatalytic reduction of $\mathrm{NAD}^{+}$to generate NADH using semiconductors with the expected mechanism shown in Scheme 3. As a result, 100 to $1000 \mathrm{~mol}$ of $\mathrm{CH}_{3} \mathrm{OH}$ can be produced from $1 \mathrm{~mol} \mathrm{NADH}$, creating the possibility for practical application. More recently, a photocatalyst/biocatalyst integrated system for highly selective methanol production directly from $\mathrm{CO}_{2}$ was reported [42]. The system was obtained by combining a newly developed graphene-based photocatalyst with sequentially coupled enzymes ( $\mathrm{FDH}, \mathrm{F}_{\mathrm{ald}} \mathrm{DH}$, and $\mathrm{ADH}$ ) as depicted in Scheme 4.

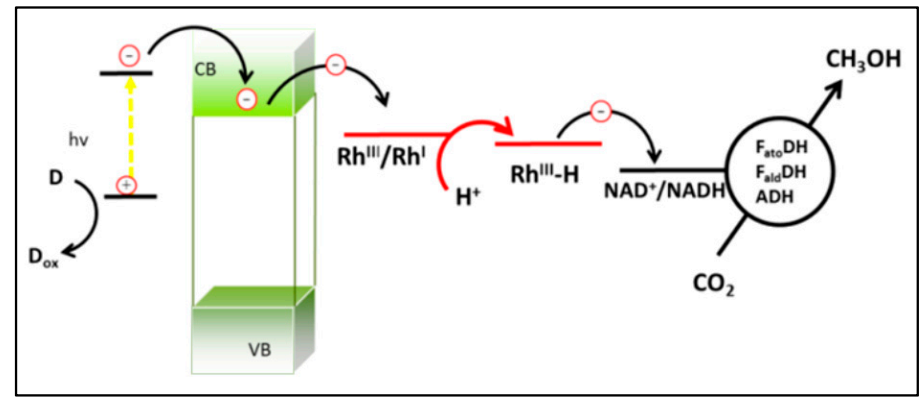

Scheme 3. Expected mechanism of NADH regeneration and further dioxide reduction to methanol [35].

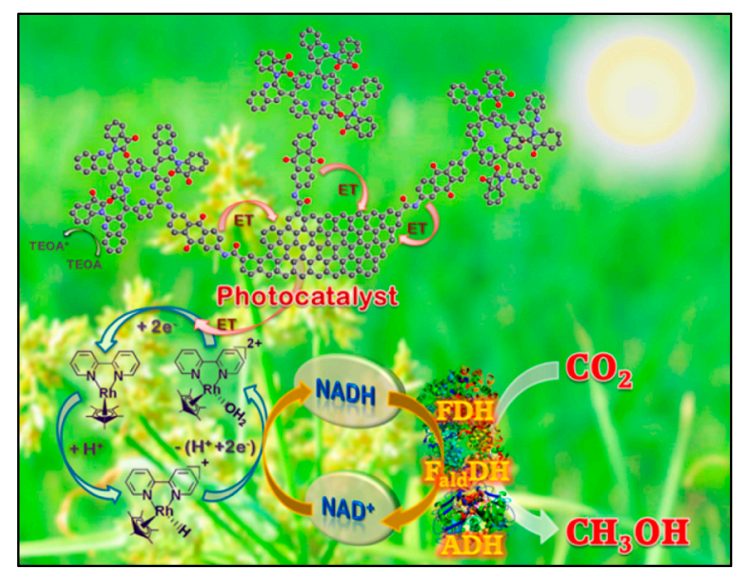

Scheme 4. Schematic illustration of the photocatalyst/biocatalyst integrated system for producing methanol from $\mathrm{CO}_{2}$ [42].

Very recently, direct injection of electrons into immobilized dehydrogenases without any sacrificial co-enzyme delivered for the electrochemical $\mathrm{CO}_{2}$ reduction to methanol around $0.15 \mathrm{ppm}$ was reported [43]. Faradaic efficiencies of around $10 \%$ were obtained. These results show for the first time that all three dehydrogenases can directly be addressed with electrochemistry without requiring any sacrificial mediator or electron donor such as NADH.

Nevertheless, the reported reaction rates and equilibrium yields are generally low and, therefore, are not suited for large-scale $\mathrm{CO}_{2}$ utilization [44]. For kinetic considerations, there is a need to intensify biocatalysts for faster and more efficient $\mathrm{CO}_{2}$ conversion. This requires the discovery of new enzymes and the engineering of reaction systems for improved catalytic efficiency.

\subsubsection{Conversion of $\mathrm{CO}_{2}$ to Methane}

It was found that the nitrogenase MoFe protein is able to catalyze the $\mathrm{CO}_{2}$ reduction to methane $\left(\mathrm{CH}_{4}\right)$ [45]. In total, $21 \mathrm{nmol}$ of $\mathrm{CH}_{4}$ can be formed using $1 \mathrm{nmol}$ of this enzyme under optimized conditions within $20 \mathrm{~min}$. The doubly substituted MoFe protein also has the capacity to catalyze the 
unprecedented formation of propylene through the reductive coupling of $\mathrm{CO}_{2}$ and acetylene. Recently, Rebelein et al. [46] observed that vanadium nitrogenase can reduce $\mathrm{CO}_{2}$ to $\mathrm{C}_{2}$ hydrocarbons involving $\mathrm{C}-\mathrm{C}$ coupling.

\subsubsection{Conversion of $\mathrm{CO}_{2}$ to Glucose}

A variety of energy-storing carbon compounds can be formed via the photosynthetic carbon reduction cycle using ATP resulting from the light-dependent reactions in conjunction with the carbon-fixing enzyme ribulose-1,5-bisphosphate carboxylase/oxygenase (RuBisCO) [47]. Inspired by this, an in vitro artificial photosynthesis system coupling the requisite enzymes of the Calvin cycle with a nanoscale photophosphorylation system was constructed for converting $\mathrm{CO}_{2}$ to sugars [48]. In total, $116 \mathrm{nmol}$ of glucose/(mL/h) can be produced with a chemical conversion efficiency approaching $96 \%$ using this photosynthetic foam.

\subsection{Conversion of $\mathrm{CO}_{2}$ to Bicarbonate}

As another strategy of $\mathrm{CO}_{2}$ conversion, an enzyme called carbonic anhydrase (CA) can directly convert $\mathrm{CO}_{2}$ to bicarbonate $\left(\mathrm{HCO}_{3}{ }^{-}\right)$via catalysis at a high turnover rate, up to $10^{6}$ per second $[49,50]$ :

$$
\mathrm{CO}_{2}+\mathrm{H}_{2} \mathrm{O} \rightarrow \mathrm{HCO}_{3}^{-}+\mathrm{H}^{+},
$$

CA has one of the fastest reaction rates among all enzymes [51]. The CA-mediated catalytic conversion of $\mathrm{CO}_{2}$ has attracted much research interest and used to assist three techniques including absorption, membrane, and mineralization in $\mathrm{CO}_{2}$ capture, sequestration, and utilization. $\mathrm{CO}_{2}$ absorption is slower in solvents, but absorption can be accelerated with CA [52]. In addition, $\mathrm{CA}$ has been also shown to allow a lower heat of desorption, thus a far lower energy requirement is feasible for $\mathrm{CO}_{2}$ capture and sequestration [53].

However, under the rough conditions of these processes such as from 50 to over $125{ }^{\circ} \mathrm{C}$ in operating temperature; high organic amine concentrations; and the presence of sulfur, nitrogen oxides and trace contaminants such as heavy metals, the stability and activity of naturally derived CA are poor, which have restricted their use [53]. To overcome these limitations, several approach have been proposed including sourcing CAs from thermophilic organisms, using protein engineering techniques to create thermotolerant enzymes, immobilizing the enzyme (for both stabilization and restriction to cooler process zones), or process modifications such as cooling the flue gas [54,55]. Recently, an innovative potassium carbonate-based absorption process, in which the CA enzyme is immobilized onto a new group of nonporous nanoparticles to improve thermal stability and chemical resistance, has been proposed to improve energy efficiency when capturing $\mathrm{CO}_{2}$ from coal combustion flue gas (shown in Figure 4) [56]. After 60-day test period at $50{ }^{\circ} \mathrm{C}$, the immobilized enzymes remained 56-88\% of their original activity as compared to a $30 \%$ activity retention when using free CA enzyme.

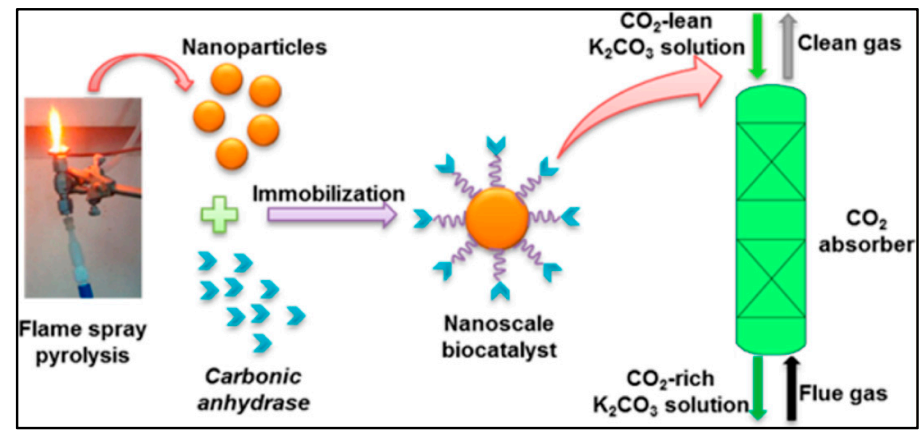

Figure 4. Schematic representation of the $\mathrm{CA}$-catalytic $\mathrm{CO}_{2}$ conversion process and potassium carbonate-based absorption process [56]. 
The catalytic conversion of $\mathrm{CO}_{2}$ by $\mathrm{CA}$ has been applied to improve the performance of membranes including enhanced efficiency, speed, and increased specificity [57]. This invention is a process for gas separation wherein carbon dioxide in a mixed gas stream is converted to bicarbonate in the temperature range of $40-85{ }^{\circ} \mathrm{C}$. The consequence is that many outlet gas streams such as flue gases can be used directly without the need for heat exchangers or other costly equipment or processes. The selective separation of $\mathrm{CO}_{2}$ from mixed gas streams has been developed using a hollow fiber membrane reactor supported by immobilized CA (shown in Figure 5) [58]. This enzyme-based membrane reactor allows $\mathrm{CO}_{2}$ at low concentrations to be separated from mixed gas streams. However, a variety of major problems including short lifetime, fouling and biofouling, separation of the enzyme from the immobilization surface, have limited the application of these enzymes in industrial settings [57].

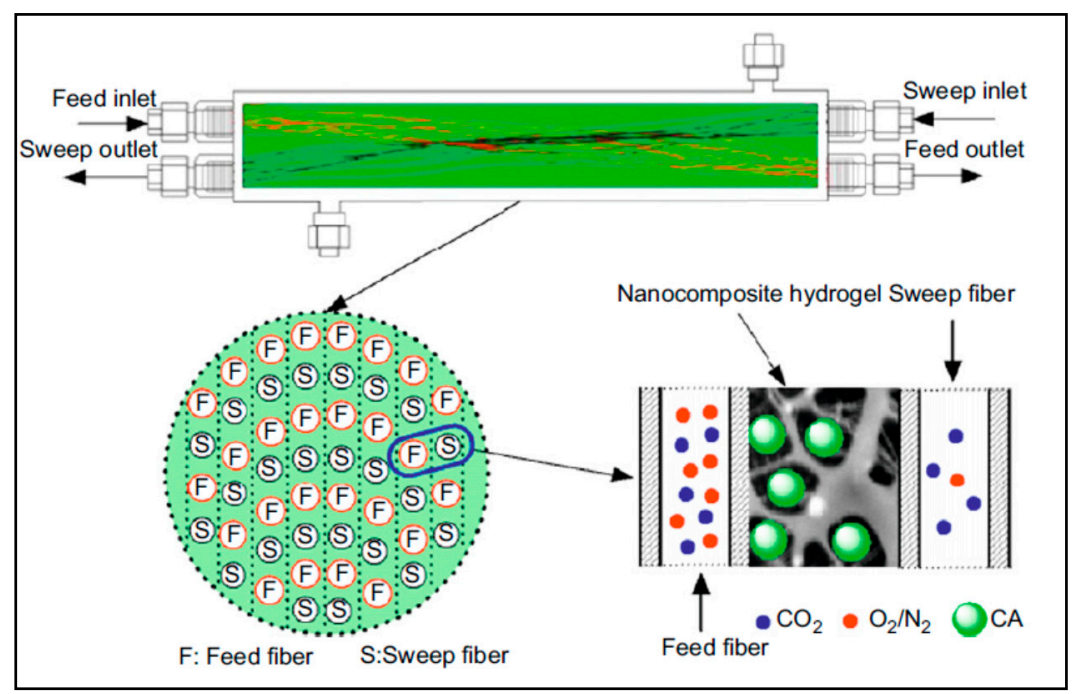

Figure 5. Schematic illustration of a hollow-fiber containing immobilized-enzyme membrane reactor [58].

Current carbon storage research has primarily focused on sequestering $\mathrm{CO}_{2}$ in underground geologic formations such as saline aquifers, depleted oil and gas fields, and unmineable coal seams [59]. Although these methods have the advantage of being relatively low-cost, sequestration in geologic formations still has several potential issues including permanence, long-term monitoring, and verification, with many unknown effects and potential risks still to be determined [60]. Thus, carbon mineralization, where $\mathrm{CO}_{2}$ is reacted with metal cations such as calcium to form calcium carbonate $\left(\mathrm{CaCO}_{3}\right)$, is considered an effective alternative to conventional geologic sequestration [61]. Note that bivalve shell composed of $\mathrm{CaCO}_{3}$ is abundant and stable biomaterials in ocean [62]. This process can be seen in Equations (2)-(6) below:

$$
\begin{gathered}
\mathrm{CO}_{2} \text { (gaseous) } \rightarrow \mathrm{CO}_{2} \text { (aqueous), } \\
\mathrm{CO}_{2} \text { (aqueous) }+\mathrm{H}_{2} \mathrm{O} \rightarrow \mathrm{H}_{2} \mathrm{CO}_{3}, \\
\mathrm{H}_{2} \mathrm{CO}_{3} \rightarrow \mathrm{HCO}_{3}{ }^{-}+\mathrm{H}^{+}, \\
\mathrm{HCO}_{3}{ }^{-} \rightarrow \mathrm{CO}_{3}{ }^{2-}+\mathrm{H}^{+}, \\
\mathrm{Ca}^{2+}+\mathrm{CO}_{3}{ }^{2-} \rightarrow \mathrm{CaCO}_{3},
\end{gathered}
$$

Because these emerging mineralization methods are rapid, environmentally friendly, and cost-effective while offering permanent carbon dioxide disposal, they have rapidly grabbed a great deal of interest [61]. However, in the whole process, $\mathrm{H}_{2} \mathrm{CO}_{3}$ formation is the rate-limiting step [63]. Thus, $\mathrm{CA}$ has recently been utilized to enhance $\mathrm{CO}_{2}$ sequestration through the conversion and mineralization 
of $\mathrm{CO}_{2}$ into $\mathrm{CaCO}_{3}$ [62]. The converting $\mathrm{CO}_{2}$ into carbonate compounds by using $\mathrm{CA}$ as a catalyst in a biomimetic approach is thermodynamically advantageous compared to other $\mathrm{CO}_{2}$ storage methods and technologies. Furthermore, the biomimetic $\mathrm{CO}_{2}$ storage approach does not need a monitoring system for potential leaks as CCS strategies do, and carbonate compounds can be used for building or industrial materials $[62,64]$. Recently, a new carbonic anhydrase isolated and characterized from the thermophilic bacterium Sulfurihydrogenibium sp. YO3AOP1 was reported [65].

Although CA can efficiently accelerate mineralization for $\mathrm{CO}_{2}$ sequestration, $\mathrm{CA}$ recycling can be a barrier. Several efforts have attempted to address this challenge. A recent study reported the strategy of CA-assisted formation of biomineralized calcium carbonate crystalline composites (CCCCs) [66]. The CCCCs produced in this study preserved their catalytic activity even after ten repeated usages, and were stable for more than 50 days at room temperature.

The success of enzymatic $\mathrm{CO}_{2}$ conversion requires the successful immobilization and stabilization of $\mathrm{CA}$, which enables enzyme recycling and improves the economics of enzymatic conversion and the eventual $\mathrm{CO}_{2}$ utilization. Various methods for immobilizing $\mathrm{CA}$ have been reported. CA immobilization on SBA-15 was explored [67]. Recently, CA has been immobilized on chitosan stabilized iron nanoparticles for the biomimetic carbonation reaction [68]. CA binding to carboxylic acid group-functionalized mesoporous silica (HOOC-FMS) was also investigated [51]. This resulted in a partial conformational change compared to the free enzyme in solution, but can allow increased protein loading density, resulting in higher enzymatic activity and immobilization efficiency. In addition, the use of bioinspired silica supporting CA for carbon capture has been presented [69]. The immobilization route was favorable compared to traditional methods due to its simplicity, mild conditions, low cost, one-step procedure, and short preparation time. More recently, a process for one-pot $\mathrm{CO}_{2}$ utilization based on the simple conversion of $\mathrm{CO}_{2}$ to bicarbonate at ambient temperature with no energy input, using the crosslinking-based composites of carboxylated polyaniline nanofibers and CA was developed [49]. The cell concentration with magnetically separable enzyme precipitate coatings was maintained as high as the first cycle after two repeated uses.

Keeping in mind the large-scale application of $\mathrm{CA}$-driven $\mathrm{CO}_{2}$ sequestration into mineral carbonates, the development of an adequate and economical means of $\mathrm{pH}$ control is presently a major research need since $\mathrm{CaCO}_{3}$ is $\mathrm{pH}$ sensitive [70]. With the available research on CA-driven processes for $\mathrm{CO}_{2}$ sequestration, smart efforts are needed with respect to choosing the right material and right CA immobilization technique so that enzyme leakage can be conquered and reusability can be enhanced, which eventually contributes to improved economic feasibility. Furthermore, more efforts are needed to build the fundamentals of mass transfer in $\mathrm{CA}$ mediated $\mathrm{CO}_{2}$ sequestration [71].

\subsection{Carboxylation Reactions}

Carboxylation is a chemical reaction in which a carboxylic acid group is introduced in a substrate. Several decarboxylase enzymes, which catalyze the decarboxylation processes, exist in cells and also have potential for biocatalytic applications of carboxylation processes, including: (i) carboxylation of epoxides; (ii) carboxylation of aromatics; (iii) carboxylation of hetero-aromatic systems; and (iv) carboxylation of aliphatic substrates [72]. The main target of carboxylation reactions by decarboxylases is to make toxic raw compounds more hydrophilic. Overall, little (or no) energy is required by these reactions [72]. Recently, these decarboxylase enzymes have been utilized in $\mathrm{CO}_{2}$ utilization as follows.

\subsubsection{Carboxylation of Epoxides}

A novel enzymatic reaction involving the metabolism of aliphatic epoxides by Xanthobacter strain Py2 has been investigated [73]. Cell extracts catalyzed the $\mathrm{CO}_{2}$-dependent carboxylation of propylene oxide (epoxypropane) to form acetoacetate and beta-hydroxybutyrate, while propylene oxide and 1,2-epoxybutane were isomerized to form acetone and methyl ethyl ketone, respectively, as this process consumes $\mathrm{CO}_{2}$. However, the potential for in vitro application and practical applicability of this process is low because the responsible enzymes could not be purified [72]. 


\subsubsection{Carboxylation of Aromatics}

There are several applications available for the enzymatic carboxylation of aromatics using decarboxylases. These processes can overcome the disadvantages of the Kolbe-Schmitt reaction because of occurring under conditions of high temperature and pressure, but cannot achieve completely mastered selectivity, which requires high energy in purification and produces waste $[74,75]$. The 4-OH benzoic acid synthesis from phenol and $\mathrm{CO}_{2}$ at room temperature and sub-atmospheric pressure of $\mathrm{CO}_{2}$ with $100 \%$ selectivity is the first application of a phenol carboxylase enzyme [6]. The use of the entire cell was excluded because the target product is further used by the bacteria as a carbon source. Thus, cells were lysed to obtain the crude extract, which was then purified using a membrane to eliminate most proteins and other cell components that are not involved in the carboxylation reaction. A turnover number of approximately 16,000 can be obtained in this clean process [75].

Recently, a new method was explored for the selective and ecological salicylic acid production by the enzymatic Kolbe-Schmitt reaction (as shown in Figure 6) [76]. In particular, salicylic acid decarboxylase (Sdc) is used for producing salicylic acid from phenol. The yeast Trichosporon moniliforme WU-0401 was enzymatically characterized with the Sdc gene heterologously expressed. More recently, Sdc enzyme has also been applied to convert $\mathrm{m}$-aminophenol to $\mathrm{p}$-aminosalicylic acid with a conversion yield of $70 \%(\mathrm{~mol} / \mathrm{mol})$ [77].

Similarly, 1,2-dihydroxybenzene (catechol) can be carboxylated to 3,4-dihydroxybenzoic acid using 3,4-dihydroxybenzoate decarboxylase in Enterobacter cloacae P241 with a conversion of $28 \%$ after $14 \mathrm{~h}$ at $30^{\circ} \mathrm{C}$ [78]. Although the enzyme was completely regioselective for its "natural" substrate, it was also able to convert phenol, 1,2-dihydroxybenzene, and m-aminophenol at very low rates, while consuming considerable amount of $\mathrm{CO}_{2}[74,79,80]$.

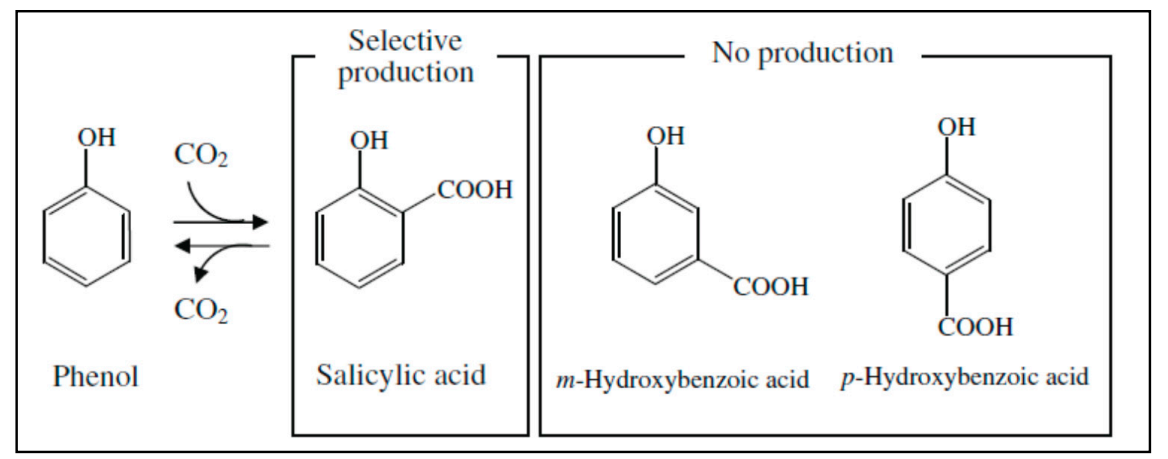

Figure 6. Reversible enzymatic conversion of salicylic acid and phenol [76].

Recently, phenolic acid decarboxylases from bacterial sources catalyzed the $\beta$-carboxylation of para-hydroxystyrene derivatives with excellent regio- and $(E / Z)$-stereoselectivity by exclusively acting at the bcarbon atom of the $\mathrm{C}=\mathrm{C}$ side chain to furnish the corresponding $(E)$-cinnamic acid derivatives in up to $40 \%$ conversion at the expense of bicarbonate as carbon dioxide source [81]. Enzyme kinetics together with the reaction thermodynamics in line with the verification of the catalytic mechanism of 2,6-dihydroxybenzoic acid decarboxylase from Rhizobium sp. with catechol as the phenolic substrate was investigated [82]. This study provides insights into the catalytic behavior of a nonoxidative aromatic decarboxylase and reveals key limitations (e.g., substrate oxidation, $\mathrm{CO}_{2}$ pressure, enzyme deactivation, and low turnover frequency) in view of the employment of this system as a "green" alternative to the Kolbe-Schmitt processes.

\subsubsection{Carboxylation of Hetero-Aromatics}

Pyrrole-2-carboxylate, a potential herbicide employed in the synthesis of various pharmaceuticals, can be synthesized from pyrrole and $\mathrm{CO}_{2}$ using pyrrole-2-carboxylate decarboxylase, which was 
obtained from Bacillus megaterium PYR2910 (as shown in Scheme 5) [83-85]. The bioconversion yield was limited to $77-81 \%$ by the reaction equilibrium [84].

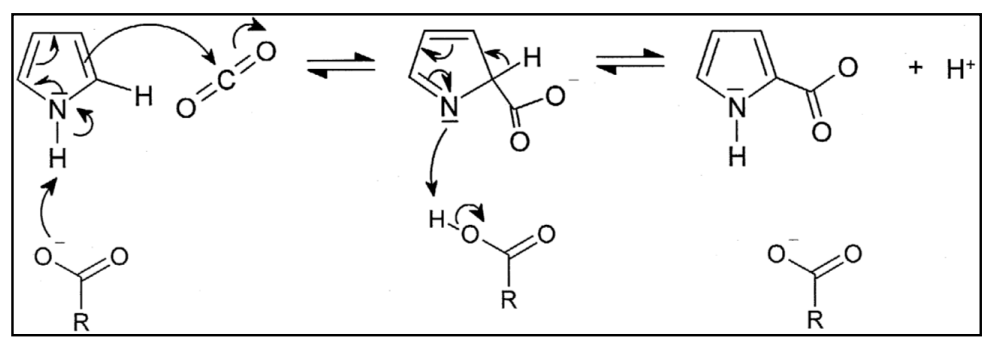

Scheme 5. Possible carboxylation mechanism [85].

\subsubsection{Carboxylation of Aliphatic Substrates}

The enzymatic synthesis of pyruvic acid from acetaldehyde and $\mathrm{CO}_{2}$ using the reverse reaction of Brewer's yeast pyruvate decarboxylase was explored as presented in Scheme $6[5,86]$. The maximum yield of $81 \%$ was achieved in $500 \mathrm{mM} \mathrm{NaHCO}-\mathrm{Na}_{2} \mathrm{CO}_{3}$ buffer and $\mathrm{pH} 11$. Especially, enzymatic reaction by lactate dehydrogenase can employed for the hydrogenation of pyruvic acid into lactic acid [86]. Thus, design a completely environmentally safe two-step enzymatic process for $\mathrm{CO}_{2}$ immobilization is possible.

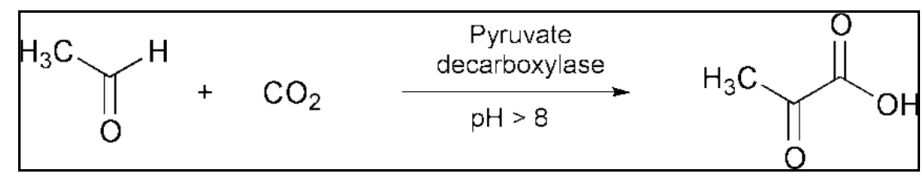

Scheme 6. Enzymatic reaction route for synthesis of pyruvic acid from $\mathrm{CO}_{2}$ and acetaldehyde [86].

Recently, a new multienzyme reaction system was investigated for $L$-lactic acid production, which is used in food, cosmetic, pharmaceutical, and chemical industries, from carbon dioxide and ethanol (shown in Scheme 7) [87]. The unique internal cofactor regeneration cycle in this synthetic route can eliminate the need for additional reagents or energy for cofactor regeneration. Up to $41 \%$ in terms of ethanol conversion can be achieved in a batch reaction, while a turnover number of 2.2 day $^{-1}$ was reached for cofactor regeneration with continuous ethanol feeding [87].

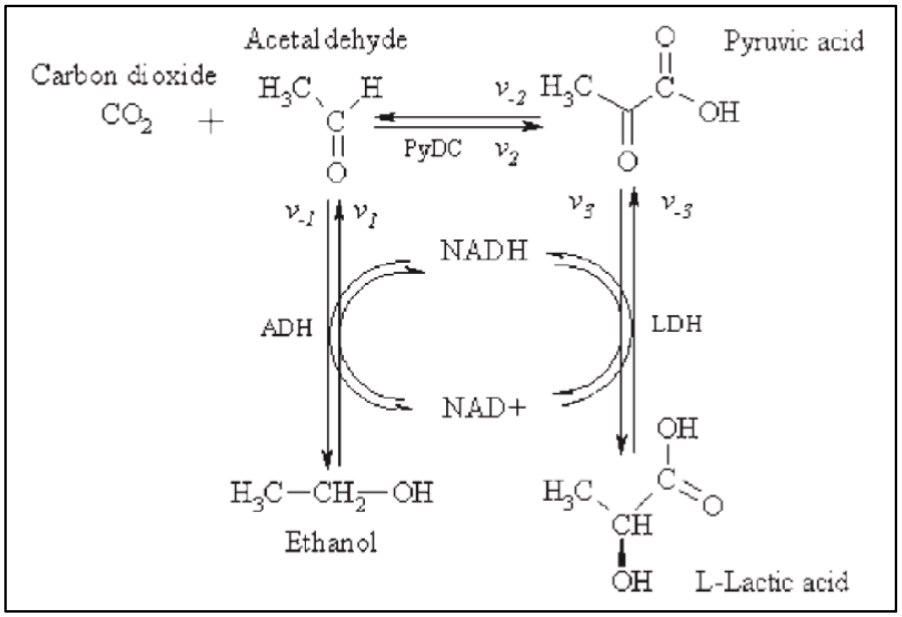

Scheme 7. Enzymatic reaction route for synthesis of L-lactic acid from $\mathrm{CO}_{2}$ and ethanol [87]. 
For more detailed information regarding carboxylation reactions, as well as the enzyme purification methods applied for those reactions, please refer to Table S1 in the Supplementary Information Section of Reference [72].

\section{Industrial Applications}

Only a limited number of examples of industrial chemical processes using $\mathrm{CO}_{2}$ as feedstock such as the Bosch-Meiser process [88] are recognized [12] because it requires large energy input due to strong bonds. This has motivated not only fundamental studies but also industrial applications of $\mathrm{CO}_{2}$ enzymatic conversion in recent years.

A successful industrial application of enzymatic $\mathrm{CO}_{2}$ conversion is using $\mathrm{CA}$ for accelerating $\mathrm{CO}_{2}$ capture [89]. The use of chemical amine solvents has been primarily employed in conventional technology for capturing pure $\mathrm{CO}_{2}$. However, these solvents require significant amounts of valuable, high-grade process heat for solvent regeneration, resulting in an inefficient process with high operating costs that suffers from significant operational and environmental issues including degradation, toxic aerosol emissions, sensitivity to flue gas contaminants, and corrosivity [89]. To solve these challenges, $\mathrm{CO}_{2}$ Solutions' technology employs the most powerful known catalyst, the enzyme CA (as shown in Figure 7), resulting in both fast $\mathrm{CO}_{2}$ absorption kinetics and significantly reduced energy consumption for carbon management.

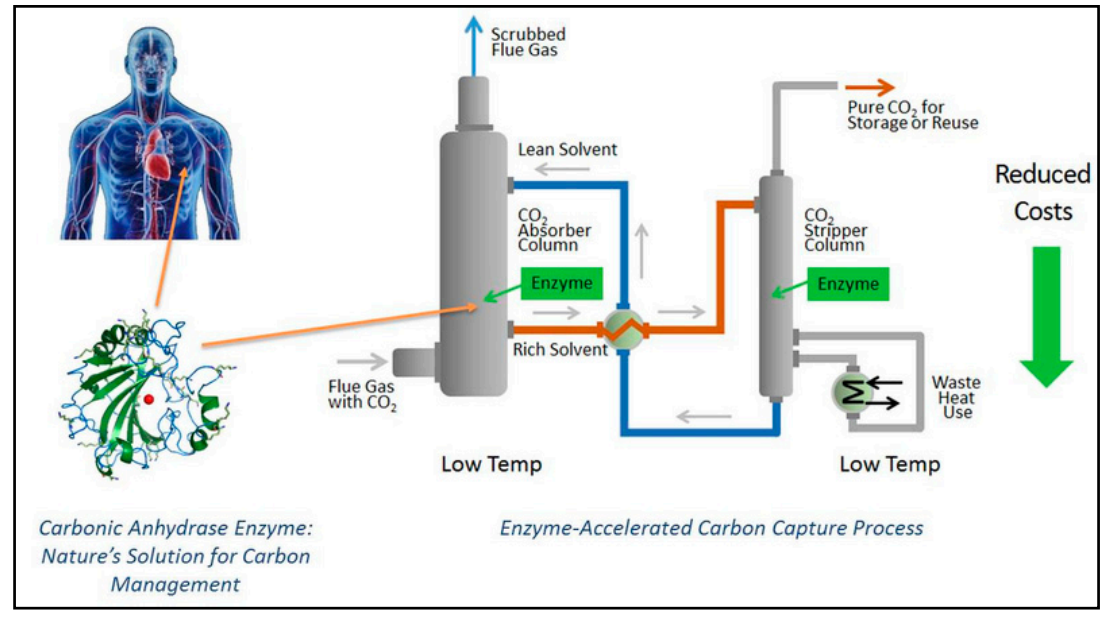

Figure 7. Schematic representation of CA-catalyzed $\mathrm{CO}_{2}$ conversion and chemical absorption [89].

Recently, the Quebec City-based company $\mathrm{CO}_{2}$ Solutions verified the results of a carbon capture demonstration project at Salaberry-de-Valleyfield near Montreal, reporting that $\mathrm{CO}_{2}$ Solutions' proprietary enzyme performed in a stable manner with negligible solvent consumption and without producing any toxic waste products (shown in Figure 8) [89,90]. Furthermore, a pilot-scale $\mathrm{CO}_{2}$ capture process was constructed at the National Carbon Capture Center in Wilsonville, AL, USA by Codexis Inc., in which the rate of $\mathrm{CO}_{2}$ absorption was enhanced 25-fold compared with the non-catalyzed reaction [91].

A process and a plant were invented for the recovery and recycling of the $\mathrm{CO}_{2}$ emissions from the cement clinker production by Lalande and Tremblay of $\mathrm{CO}_{2}$ Solution [92]. In this process, a gas/liquid $\mathrm{CO}_{2}$ packed column absorption catalyzed by $\mathrm{CA}$ is used and subsequent with the production of limestone $\left(\mathrm{CaCO}_{3}\right)$. The sequence is accomplished when the $\mathrm{CaCO}_{3}$ is used as first class raw material for the fabrication of Portland cement.

Climostat Ltd. (Cheshire, UK) has filed a patent application for an enzymatic process that converts $\mathrm{CO}_{2}$ and methane to formic acid, a valuable commodity chemical [93]. One fifth of a ton of methane (about $£ 50$ worth) would be potentially converted into $£ 720$ worth of formic acid. Even after 
conversion costs are taken into account, the process is expected to be of significant commercial value and especially so when any carbon levy is taken into account. Further value could be added by using the resulting formic acid as a feedstock for higher-value materials. In addition, Sweetwater Energy Inc. (New York, NY, USA) and Naturally Scientific Technologies Ltd. (Buckinghamshire, UK) announced a joint venture to produce sugar from carbon dioxide waste from facilities such as ethanol plants or natural-gas powered power plants [94].

Recently, within the "Biotechnology 2020+" strategy process, the funding measure "Basic technologies for a next generation of biotechnological processes" supports three selected projects with regards to enzymatic conversion of $\mathrm{CO}_{2}$ with a total budget of 4.3 million Euros [95,96]. In addition, the US Department of Energy (DOE), through the National Energy Technology Labs (NETL) and academic partners, is funding a spectrum of research projects investigating closed-cycle catalysts to convert $\mathrm{CO}_{2}$ to commodity products that are ideally energy and carbon neutral [97]. Even though these projects are still focused primarily on basic research, biotechnological approaches will play an important role in $\mathrm{CO}_{2}$ utilization in the future [95]. With the current global dependency on fossil fuels for energy production, these approaches are expected provide a means to reduce human induced climate change [98].

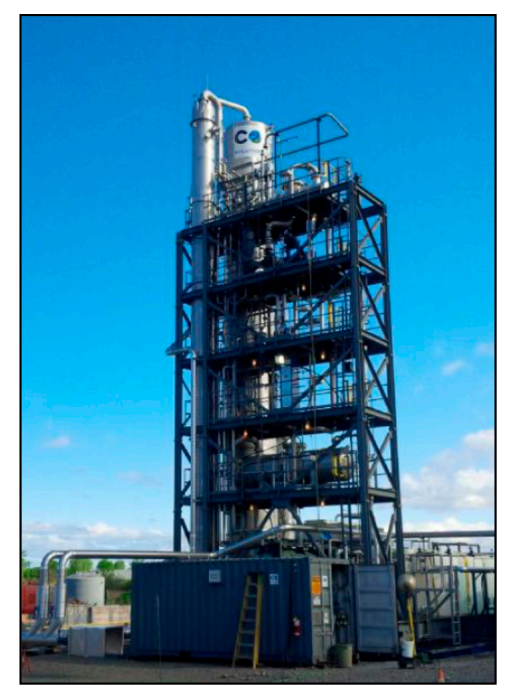

Figure 8. Industrial application of CA-catalyzed $\mathrm{CO}_{2}$ conversion and chemical absorption [89].

\section{Barriers and Future Perspectives}

Enzymes are generally expensive with poor stability, activity, and reusability, which restrict their industrial applications. Several enzymatic technologies such as enzyme modification and enzyme immobilization need further development for reducing cost, improving the activity/stability of the enzymes, and enhancing reusability, which eventually improves economic feasibility. Besides, low reaction rate is one of main barriers for the application of enzymatic $\mathrm{CO}_{2}$ conversion in industry. For kinetic concerns, biocatalysts are needed for faster and more efficient $\mathrm{CO}_{2}$ conversion. Thus, the discovery of novel enzymes as well as the reaction systems engineering are required to improve catalytic efficiency.

Especially, cofactor-dependent reactions widely occur in the enzymatic conversion of $\mathrm{CO}_{2}$. However, some cofactors are expensive and have limited availability, which severely limits large-scale applications. Thus, considerable research effort should be applied toward the discovery of new low-cost and low-energy approaches for cofactor regeneration and reuse [2].

In addition, only a few multienzyme routes have been constructed in vitro due to reaction complexity. Therefore, designing and/or constructing of number of novel multienzyme routes are imperative to sustainably produce fuels and chemicals from $\mathrm{CO}_{2}$ [2]. 
Furthermore, it is important to consider that the technologies for $\mathrm{CO}_{2}$ conversion based on chemical, photochemical, and electrochemical methods also show great application potential [99]. Thus, combining these methodologies with enzymatic conversion is expected to be beneficial in terms of selectivity and productivity. These combination strategies should be further studied and evaluated.

For an industrial exploitation, the design of a suitable bioreactor is a key issue [40]. Furthermore, the unit operations for the separation of mixture including biological molecules differ from their counterparts in the chemical industry. Much effort in separation in downstream needs to investigate and evaluate. Especially, the use of enzymes within reactive separation to enhance both reaction and separation has increased its research interest. Because enzymes are sensitive to higher temperatures, many works are needed to develop. In addition, the development of thermodynamic data and models for description of systems containing enzyme as well as development of synthesis/design tools are crucial to support the quick implementation of those systems [100].

Although a considerable number of studies have been carried out, substantial scientific and technical advances are still needed for a link between fundamental research and industrial application of enzymatic $\mathrm{CO}_{2}$ conversion.

\section{Conclusions}

Enzymatic $\mathrm{CO}_{2}$ conversion represents a viable and promising new technology for both greenhouse gas recycling and efficient production of fuels and chemicals. In this review, we attempted to elucidate the major challenges for transitioning enzymatic conversion from promise to reality. Although there is much excitement about the potential of enzymatic $\mathrm{CO}_{2}$ conversion as well as several real industrial applications, much work is still required in the field to discover facile and low-energy $\mathrm{CO}_{2}$ conversion routes; improve catalytic efficiency; integrate with chemical, photochemical, and electrochemical technologies for higher efficiency; and assess downstream processes for large-scale utilization. There are several real industrial application examples that are working, thus, we are not so far from the extension of the technology in the industry.

Acknowledgments: This research was supported by C1 Gas Refinery Program through the National Research Foundation of Korea (NRF) funded by the Ministry of Science, ICT \& Future Planning (NRF-2016M3D3A1A01913262). This study was also supported by Priority Research Centers Program through the National Research Foundation of Korea (NRF) funded by the Ministry of Education (2014R1A6A1031189).

Author Contributions: Nguyen Van Duc Long designed the paper, conducted the literature review, and wrote the paper. Jintae Lee advised enzymatic conversion. Kee-Kahb Koo advised novel applications. Patricia Luis and Moonyong Lee equally conceived the core concepts for the research and provided academic advice. All authors collaborated in the preparation, revisions, and general editing of this manuscript.

Conflicts of Interest: The authors declare no conflict of interest.

\section{Abbreviations}

The following abbreviations are used in this manuscript:

$\begin{array}{ll}\mathrm{ADH} & \text { Alcohol dehydrogenase } \\ \mathrm{CO} & \text { Carbon monoxide } \\ \mathrm{CO}_{2} & \text { Carbon dioxide } \\ \mathrm{CCS} & \mathrm{CO}_{2} \text { capture and storage } \\ \mathrm{CODH} & \text { Carbon monoxide dehydrogenases } \\ \mathrm{CA} & \text { Carbonic anhydrase } \\ \mathrm{FDH} & \text { Formate dehydrogenase } \\ \mathrm{CCCCs} & \text { Calcium carbonate crystalline composites } \\ \mathrm{F}_{\text {ald }}{ }^{\mathrm{DH}} & \text { Formaldehyde dehydrogenase } \\ \mathrm{CH}_{4} & \text { Methane } \\ \mathrm{HCO}_{3}- & \text { Bicarbonate } \\ \mathrm{HOOC}_{-} \mathrm{FMS} & \text { Carboxylic acid group-functionalized mesoporous silica } \\ \mathrm{RuBisC}^{-} & \text {Ribulose-1,5-bisphosphate carboxylase/oxygenase }\end{array}$




\section{References}

1. Leung, D.Y.C.; Caramanna, G.; Mercedes Maroto-Valer, M. An overview of current status of carbon dioxide capture and storage technologies. Renew. Sustain. Energy Rev. 2014, 39, 426-443. [CrossRef]

2. Shi, J.; Jiang, Y.; Jiang, Z.; Wang, X.; Wang, X.; Zhang, S.; Han, P.; Yan, C. Enzymatic conversion of carbon dioxide. Chem. Soc. Rev. 2015, 44, 5981-6000. [CrossRef] [PubMed]

3. Milani, D.; Khalilpour, R.; Zahedi, G.; Abbas, A. A model-based analysis of $\mathrm{CO}_{2}$ utilization in methanol synthesis plant. J. $\mathrm{CO}_{2}$ Util. 2015, 10, 12-22. [CrossRef]

4. Anthofer, M.H.; Wilhelm, M.E.; Cokoja, M.; Kühn, F.E. Valorization of carbon dioxide to organic products with organocatalysts. In Transformation and Utilization of Carbon Dioxide; Bhanage, B.M., Arai, M., Eds.; Springer: Berlin/Heidelberg, Germany, 2014.

5. Aresta, M.; Dibenedetto, A.; Quaranta, E. Reaction Mechanisms in Carbon Dioxide Conversion; Springer: Berlin/Heidelberg, Germany, 2015; pp. 347-371.

6. Aresta, M.; Quaranta, E.; Liberio, R.; Dileo, C.; Tommasi, I. Enzymatic synthesis of 4-OH-benzoic acid from phenol and $\mathrm{CO}_{2}$ : The first example of a biotechnological application of a carboxylase enzyme. Tetrahedron 1998, 54, 8841-8846. [CrossRef]

7. Obert, R.; Dave, B.C. Enzymatic conversion of carbon dioxide to methanol: Enhanced methanol production in silica sol-gel matrices. J. Am. Chem. Soc. 1999, 121, 12192-12193. [CrossRef]

8. Yong, J.K.J.; Stevens, G.W.; Caruso, F.; Kentish, S.E. The use of carbonic anhydrase to accelerate carbon dioxide capture processes. J. Chem. Technol. Biotechnol. 2015, 90, 3-10. [CrossRef]

9. Kim, D.H.; Vinoba, M.; Shin, W.S.; Lim, K.S.; Jeong, S.K.; Kim, S.K. Biomimetic sequestration of carbon dioxide using an enzyme extracted from oyster shell. Korean J. Chem. Eng. 2011, 28, 2081-2085. [CrossRef]

10. Fuchs, G. Alternative pathways of carbon dioxide fixation: Insights into the early evolution of life? Annu. Rev. Microbiol. 2011, 65, 631-658. [CrossRef] [PubMed]

11. Berg, I.A.; Kockelkorn, D.; Ramos-Vera, W.H.; Say, R.; Zarzycki, J.; Fuchs, G. Autotrophic carbon fixation in biology: Pathways, rules, and speculations. In Carbon Dioxide as Chemical Feedstock; Aresta, M., Ed.; WILEY-VCH Verlag GmbH \& Co. KGaA: Weinheim, Germany, 2010; pp. 33-53.

12. Alissandratos, A.; Easton, C.J. Biocatalysis for the application of $\mathrm{CO}_{2}$ as a chemical feedstock. Beilstein J. Org. Chem. 2015, 11, 2370-2387. [CrossRef] [PubMed]

13. Erb, T.J. Carboxylases in natural and synthetic microbial pathways. Appl. Environ. Microbiol. 2011, 77, 8466-8477. [CrossRef] [PubMed]

14. Bar-Even, A.; Noor, E.; Lewis, N.E.; Milo, R. Design and analysis of synthetic carbon fixation pathways. Proc. Natl. Acad. Sci. USA 2010, 107, 8889-8894. [CrossRef] [PubMed]

15. Ducat, D.C.; Silver, P.A. Improving carbon fixation pathways. Curr. Opin. Chem. Biol. 2012, 16, 337-344. [CrossRef] [PubMed]

16. Bar-Even, A.; Noor, E.; Milo, R. A survey of carbon fixation pathways through a quantitative lens. J. Exp. Bot. 2012, 63, 2325-2342. [CrossRef] [PubMed]

17. Woolerton, T.W.; Sheard, S.; Reisner, E.; Pierce, E.; Ragsdale, S.W.; Armstrong, F.A. Efficient and clean photoreduction of $\mathrm{CO}_{2}$ to $\mathrm{CO}$ by enzyme-modified $\mathrm{TiO}_{2}$ nanoparticles using visible light. J. Am. Chem. Soc. 2010, 132, 2132-2133. [CrossRef] [PubMed]

18. Ragsdale, S. Life with carbon monoxide. Crit. Rev. Biochem. Mol. Biol. 2004, 39, 165-195. [CrossRef] [PubMed]

19. Parkin, A.; Seravalli, J.; Vincent, K.A.; Ragsdale, S.W.; Armstrong, F.A. Rapid and efficient electrocatalytic $\mathrm{CO}_{2} / \mathrm{CO}$ interconversions by Carboxydothermus hydrogenoformans $\mathrm{CO}$ dehydrogenase I on an electrode. J. Am. Chem. Soc. 2007, 129, 10328-10329. [CrossRef] [PubMed]

20. Appel, A.M.; Bercaw, J.E.; Bocarsly, A.B.; Dobbek, H.; DuBois, D.L.; Dupuis, M.; Ferry, J.G.; Fujita, E.; Hille, R.; Kenis, P.J.A.; et al. Frontiers, opportunities, and challenges in biochemical and chemical catalysis of $\mathrm{CO}_{2}$. Chem. Rev. 2013, 113, 6621-6658. [CrossRef] [PubMed]

21. Shin, W.; Lee, S.H.; Shin, J.W.; Lee, S.P.; Kim, Y. Highly selective electrocatalytic conversion of $\mathrm{CO}_{2}$ to $\mathrm{CO}$ at $-0.57 \mathrm{~V}$ (NHE) by carbon monoxide dehydrogenase from Moorella thermoacetica. J. Am. Chem. Soc. 2003, 125, 14688-14689. [CrossRef] [PubMed]

22. Woolerton, W.; Sheard, S.; Pierce, E.; Ragsdale, S.W.; Armstrong, F.A. $\mathrm{CO}_{2}$ photoreduction at enzyme-modified metal oxide nanoparticles. Energy Environ. Sci. 2011, 4, 2393-2399. [CrossRef] 
23. Bachmeier, A.; Wang, V.C.C.; Woolerton, T.W.; Bell, S.; Fontecilla-Camps, J.C.; Can, M.; Ragsdale, S.W.; Chaudhary, Y.S.; Armstrong, F.A. How light-harvesting semiconductors can alter the bias of reversible electrocatalysts in favor of $\mathrm{H}_{2}$ production and $\mathrm{CO}_{2}$ reduction. J. Am. Chem. Soc. 2013, 135, 15026-15032. [CrossRef] [PubMed]

24. Alvarez-Guerra, M.; Quintanilla, S.; Irabien, A. Conversion of carbon dioxide into formate using a continuous electrochemical reduction process in a lead cathode. Chem. Eng. J. 2012, 207-208, 278-284. [CrossRef]

25. Rees, N.V.; Compton, R.G. Sustainable energy: A review of formic acid electrochemical fuel cells. J. Solid State Electrochem. 2011, 15, 2095-2100. [CrossRef]

26. Innocent, B.; Liaigre, D.; Pasquier, D.; Ropital, F.; Léger, J.-M.; Kokoh, K.B. Electroreduction of carbon dioxide to formate on lead electrode in aqueous medium. J. Appl. Electrochem. 2009, 39, 227-232. [CrossRef]

27. Neuhauser, W.; Steininger, M.; Haltrich, D.; Kulbe, K.D.; Nidetzky, B. A pH-controlled fed-batch process can overcome inhibition by formate in NADH-dependent enzymatic reductions using formate dehydrogenase-catalyzed coenzyme regeneration. Biotechnol. Bioeng. 1998, 60, 277-282. [CrossRef]

28. Ruschig, U.; Müller, U.; Willnow, P.; Höpner, T. $\mathrm{CO}_{2}$ reduction to formate by NADH catalysed by formate dehydrogenase from Pseudomonas oxalaticus. Eur. J. Biochem. 1976, 70, 325-330. [CrossRef] [PubMed]

29. Tishkov, V.I.; Popov, V.O. Catalytic mechanism and application of formate dehydrogenase biochemistry. Biochemistry 2004, 69, 1252-1267. [PubMed]

30. Lu, Y.; Jiang, Z.; $\mathrm{Xu}, \mathrm{S}$; $\mathrm{Wu}, \mathrm{H}$. Efficient conversion of $\mathrm{CO}_{2}$ to formic acid by formate dehydrogenase immobilized in a novel alginate-silica hybrid gel. Catal. Today 2006, 115, 263-268. [CrossRef]

31. Reda, T.; Plugge, C.M.; Abram, N.J.; Hirst, J. Reversible interconversion of carbon dioxide and formate by an electroactive enzyme. Proc. Natl. Acad. Sci. USA 2008, 105, 10654-10658. [CrossRef] [PubMed]

32. Yadav, R.K.; Baeg, J.O.; Oh, G.H.; Park, N.J.; Kong, K.J.; Kim, J.H.; Hwang, D.W.; Biswas, S.K. A photocatalyst-enzyme coupled artificial photosynthesis system for solar energy in production of formic acid from $\mathrm{CO}_{2}$. J. Am. Chem. Soc. 2012, 134, 11455-11461. [CrossRef] [PubMed]

33. Yadav, R.K.; Baeg, J.O.; Kumar, A.; Kong, K.J.; Oh, G.H.; Park, N.J. Graphene-BODIPY as a photocatalyst in the photocatalytic-biocatalytic coupled system for solar fuel production from $\mathrm{CO}_{2}$. J. Mater. Chem. A 2014, 2, 5068-5076. [CrossRef]

34. Kim, S.; Kim, M.K.; Lee, S.H.; Yoon, S.H.; Jung, K.D. Conversion of $\mathrm{CO}_{2}$ to formate in an electroenzymatic cell using Candida boidinii formate dehydrogenase. J. Mol. Catal. B Enzym. 2014, 102, 9-15. [CrossRef]

35. Aresta, M.; Dibenedetto, A.; Baran, T.; Angelini, A.; Łabuz, P.; Macyk, W. An integrated photocatalytic-enzymatic system for the reduction of $\mathrm{CO}_{2}$ to methanol in bio-glycerol-water. Beilstein J. Org. Chem. 2014, 10, 2556-2565. [CrossRef] [PubMed]

36. Xu, S.; Lu, Y.; Li, J.; Jiang, Z.; Wu, H. Efficient conversion of $\mathrm{CO}_{2}$ to methanol catalyzed by three dehydrogenases Co-encapsulated in an alginate-silica (ALG-SiO 2$)$ hybrid gel. Ind. Eng. Chem. Res. 2006, 45, 4567-4573. [CrossRef]

37. Shchipunov, Y.A.; Karpenkoa, T.Y.; Bakuninab, I.Y.; Burtsevab, Y.V.; Zvyagintseva, T.N. A new precursor for the immobilization of enzymes inside sol-gel-derived hybrid silica nanocomposites containing polysaccharides. J. Biochem. Biophys. Methods 2004, 58, 25-38. [CrossRef]

38. Meyer, M.; Fischer, A.; Hoffmann, H. Novel ringing silica gels that do not shrink. J. Phys. Chem. B 2002, 106, 1528-1533. [CrossRef]

39. Sun, D.; Zhang, R.; Liu, Z.; Huang, Y.; Wang, Y.; He, J.; Han, B.; Yang, G. Polypropylene/silica nanocomposites prepared by in-situ sol-gel reaction with the aid of $\mathrm{CO}_{2}$. Macromolecules 2005, 38, 5617-5624. [CrossRef]

40. Sultana, S.; Sahoo, P.C.; Martha, S.; Parida, K. A review of harvesting clean fuels from enzymatic $\mathrm{CO}_{2}$ reduction. RSC Adv. 2016, 6, 44170-44194. [CrossRef]

41. Luo, J.; Meyer, A.S.; Mateiu, R.V.; Pinelo, M. Cascade catalysis in membranes with enzyme immobilization for multi-enzymatic conversion of $\mathrm{CO}_{2}$ to methanol. New Biotechnol. 2015, 32, 319-327. [CrossRef] [PubMed]

42. Yadav, R.K.; Oh, G.H.; Park, N.J.; Kumar, A.; Kong, K.J.; Baeg, J.O. Highly selective solar-driven methanol from $\mathrm{CO}_{2}$ by a photocatalyst/biocatalyst integrated system. J. Am. Chem. Soc. 2014, 136, 16728-16731. [CrossRef] [PubMed]

43. Schlager, S.; Dumitru, L.M.; Haberbauer, M.; Fuchsbauer, A.; Neugebauer, H.; Hiemetsberger, D.; Wagner, A.; Portenkirchner, E.; Sariciftci, N.S. Electrochemical reduction of carbon dioxide to methanol by direct injection of electrons into immobilized enzymes on a modified electrode. ChemSusChem 2016, 9, 631-635. [CrossRef] [PubMed] 
44. Baskaya, F.S.; Zhao, X.; Flickinger, M.C.; Wang, P. Thermodynamic feasibility of enzymatic reduction of carbon dioxide to methanol. Appl. Biochem. Biotechnol. 2010, 162, 391-398. [CrossRef] [PubMed]

45. Yang, Z.Y.; Moure, V.R.; Dean, D.R.; Seefeldt, L.C. Carbon dioxide reduction to methane and coupling with acetylene to form propylene catalyzed by remodeled nitrogenase. Proc. Natl. Acad. Sci. USA 2012, 109, 19644-19648. [CrossRef] [PubMed]

46. Rebelein, J.G.; Hu, Y.; Ribbe, M.W. Differential Reduction of $\mathrm{CO}_{2}$ by molybdenum and vanadium nitrogenases. Angew. Chem. Int. Ed. Engl. 2014, 53, 11543-11546. [CrossRef] [PubMed]

47. Bassham, J.A.; Calvin, M. The path of carbon in photosynthesis. In Die $\mathrm{CO}_{2}$-Assimilation/The Assimilation of Carbon Dioxide; Springer: Berlin/Heidelberg, Germany, 1960; Volume 5, pp. 884-922.

48. Wendell, D.; Todd, J.; Montemagno, C. Artificial photosynthesis in ranaspumin-2 based foam. Nano Lett. 2010, 10, 3231-3236. [CrossRef] [PubMed]

49. Gil, H.S.; Jeon, H.C.; Kim, H.S.; Jun, S.H.; Jin, E.S.; Kim, J.B. One-pot enzymatic conversion of carbon dioxide and utilization for improved microbial growth. Environ. Sci. Technol. 2015, 49, 4466-4472.

50. Lindskog, S.; Coleman, J.E. The catalytic mechanism of carbonic anhydrase. Proc. Natl. Acad. Sci. USA 1973, 70, 2505-2508. [CrossRef] [PubMed]

51. Yu, Y.; Chen, B.; Qi, W.; Li, X.; Shin, Y.; Lei, C.; Liu, J. Enzymatic conversion of $\mathrm{CO}_{2}$ to bicarbonate in functionalized mesoporous silica. Microporous Mesoporous Mater. 2012, 153, 166-170. [CrossRef] [PubMed]

52. Blais, R.; Rogers, P. Process and Apparatus for the Treatment of Carbon Dioxide with Carbonic Anhydrase. U.S. Patent 6524843, 25 February 2003.

53. Savile, C.K.; Lalonde, J.J. Biotechnology for the acceleration of carbon dioxide capture and sequestration. Curr. Opin. Biotechnol. 2011, 22, 818-823. [CrossRef] [PubMed]

54. Newman, L.M.; Clark, L.; Ching, C.; Zimmerma, S. Carbonic Anhydrase Polypeptides and Uses Thereof. U.S. Patent WO10081007, 15 July 2010.

55. Daigle, R.; Desrochers, M. Carbonic Anhydrase Having Increased Stability under High Temperature Conditions. U.S. Patent 7521217, 21 April 2009.

56. Zhang, S.H.; Lu, H.; Lu, Y.Q. Enhanced stability and chemical resistance of a new nanoscale biocatalyst for accelerating $\mathrm{CO}_{2}$ absorption into a carbonate solution. Environ. Sci. Technol. 2013, 47, 13882-13888. [CrossRef] [PubMed]

57. Trachtenberg, M.C. Novel Enzyme Compositions for Removing Carbon Dioxide from a Mixed Gas. U.S. Patent 20080003662, 3 January 2008.

58. Zhang, Y.T.; Zhang, L.; Chen, H.L.; Zhang, H.M. Selective separation of low concentration $\mathrm{CO}_{2}$ using hydrogel immobilized CA enzyme based hollow fiber membrane reactors. Chem. Eng. Sci. 2010, 65, 3199-3207. [CrossRef]

59. Romanov, V.; Soong, Y.; Carney, C.; Rush, G.E.; Nielsen, B.; O'Connor, W. Mineralization of carbon dioxide: A literature review. ChemBioEng Rev. 2015, 2, 231-256. [CrossRef]

60. Park, H.S.; Han, J.Y.; Lee, J.S.; Kim, K.M.; Jo, H.J.; Min, B.R. Comparison of two processes forming $\mathrm{CaCO}_{3}$ precipitates by electrolysis. Energies 2016, 9, 1052. [CrossRef]

61. Zhang, X.; Yan, S.; Tyagi, R.D.; Surampalli, R.Y.; Zhang, T.C. Enzymatic sequestration of carbon dioxide. In Carbon Capture and Storage: Physical, Chemical, and Biological Methods; Surampalli, R.Y., Zhang, T.C., Tyagi, R.D., Naidu, R., Gurjar, B.R., Ojha, C.S.P., Yan, S., Brar, S.K., Ramakrishnan, A., Kao, C.M., Eds.; ASCE: Reston, VI, USA, 2015.

62. Lee, S.W.; Park, S.B.; Jeong, S.K.; Lim, K.S.; Lee, S.H.; Trachtenberg, M.C. On carbon dioxide storage based on biomineralization strategies. Micron 2010, 41, 273-282. [CrossRef] [PubMed]

63. Mirjafari, P.; Asghari, K.; Mahinpey, N. Investigating the application of enzyme carbonic anhydrase for $\mathrm{CO}_{2}$ sequestration purposes. Ind. Eng. Chem. Res. 2007, 46, 921-926. [CrossRef]

64. Jang, J.G.; Kim, G.M.; Kim, H.J.; Lee, H.K. Review on recent advances in $\mathrm{CO}_{2}$ utilization and sequestration technologies in cement-based materials. Construct. Build. Mater. 2016, 127, 762-773. [CrossRef]

65. Capasso, C.; Luca, V.D.; Carginale, V.; Caramuscio, P.; Cavalheiro, C.F.N.; Cannio, R.; Rossi, M. Characterization and properties of a new thermoactive and thermostable carbonic anhydrase. Chem. Eng. Trans. 2012, 27, 271-276.

66. Hwang, E.T.; Gang, H.; Chung, J.; Gu, M.B. Carbonic anhydrase assisted calcium carbonate crystalline composites as a biocatalyst. Green Chem. 2012, 14, 2216-2220. [CrossRef] 
67. Vinoba, M.; Kim, D.H.; Lim, K.S.; Jeong, S.K.; Lee, S.W.; Alagar, M. Biomimetic sequestration of $\mathrm{CO}_{2}$ and reformation to $\mathrm{CaCO}_{3}$ using bovine carbonic anhydrase immobilized on SBA-15. Energy Fuel 2011, 25, 438-445. [CrossRef]

68. Yadav, R.; Joshi, M.; Wanjari, S.; Prabhu, C.; Kotwal, S.; Satyanarayanan, T.; Rayalu, S. Immobilization of carbonic anhydrase on chitosan stabilized iron nanoparticles for the carbonation reaction. Water Air Soil Pollut. 2012, 223, 5345-5356. [CrossRef]

69. Forsyth, C.; Yip, T.W.S.; Patwardhan, S.V. $\mathrm{CO}_{2}$ sequestration by enzyme immobilized onto bioinspired silica. Chem. Commun. 2013, 49, 3191-3193. [CrossRef] [PubMed]

70. Shekh, A.Y.; Krishnamurthi, K.; Mudliar, S.N.; Yadav, R.R.; Fulke, A.B.; Devi, S.S.; Chakrabarti, T. Recent advancements in carbonic anhydrase-driven processes for $\mathrm{CO}_{2}$ sequestration: Minireview. Crit. Rev. Environ. Sci. Technol. 2012, 42, 1419-1440. [CrossRef]

71. Yadav, R.R.; Kannan, K.; Sandeep, M.; Devi, S.S.; Naoghare, P.K.; Bafana, A.; Chakrabarti, T. Carbonic anhydrase mediated carbon dioxide sequestration: Promises, challenges and future prospects. J. Basic Microbiol. 2014, 54, 472-481. [CrossRef] [PubMed]

72. Glueck, S.M.; Gümüs, S.; Fabian, W.M.; Faber, K. Biocatalytic carboxylation. Chem. Soc. Rev. 2010, 39, 313-328. [CrossRef] [PubMed]

73. Allen, J.R.; Ensign, S.A. Carboxylation of epoxides to beta-keto acids in cell extracts of Xanthobacter strain Py2. J. Bacteriol. 1996, 178, 1469-1472. [CrossRef] [PubMed]

74. Wuensch, C.; Glueck, S.M.; Gross, J.; Koszelewski, D.; Schober, M.; Faber, K. Regioselective enzymatic carboxylation of phenols and hydroxystyrene derivatives. Org. Lett. 2012, 14, 1974-1977. [CrossRef] [PubMed]

75. Aresta, M.; Dibenedetto, A. Development of environmentally friendly syntheses: Use of enzymes and biomimetic systems for the direct carboxylation of organic substrates. Rev. Mol. Biotechnol. 2002, 90, 113-128. [CrossRef]

76. Kirimura, K.; Gunji, H.; Wakayama, R.; Hattori, T.; Ishii, Y. Enzymatic Kolbe-Schmitt reaction to form salicylic acid from phenol: Enzymatic characterization and gene identification of a novel enzyme, Trichosporon moniliiforme salicylic acid decarboxylase. Biochem. Biophys. Res. Commun. 2010, 394, 279-284. [CrossRef] [PubMed]

77. Kirimura, K.; Yanaso, S.; Kosaka, S.; Koyama, K.; Hattori, T.; Ishii, Y. Production of p-aminosalicylic acid through enzymatic Kolbe-Schmitt reaction catalyzed by reversible salicylic acid decarboxylase. Chem. Lett. 2011, 40, 206-208. [CrossRef]

78. Yoshida, T.; Inami, Y.; Matsui, T.; Nagasawa, T. Regioselective carboxylation of catechol by 3,4-dihydroxybenzoate decarboxylase of Enterobacter cloacae P. Biotechnol. Lett. 2010, 32, 701-705. [CrossRef] [PubMed]

79. Matsui, T.; Yoshida, T.; Yoshimura, T.; Nagasawa, T. Regioselective carboxylation of 1,3-dihydroxybenzene by 2,6-dihydroxybenzoate decarboxylase of Pandoraea sp. 12B-2. Appl. Microbiol. Biotechnol. 2006, 73, 95-102. [CrossRef] [PubMed]

80. Iwasaki, Y.; Kino, K.; Nishide, H.; Kirimura, K. Regioselective and enzymatic production of $\gamma$-resorcylic acid from resorcinol using recombinant Escherichia coli cells expressing a novel decarboxylase gene. Biotechnol. Lett. 2007, 29, 819-822. [CrossRef] [PubMed]

81. Wuensch, C.; Pavkov-Keller, T.; Steinkellner, G.; Gross, J.; Fuchs, M.; Hromic, A.; Lyskowski, A.; Fauland, K.; Gruber, K.; Glueck, S.M.; et al. Regioselective enzymatic $\beta$-carboxylation of para-hydroxy-styrene derivatives catalyzed by phenolic acid decarboxylases. Adv. Synth. Catal. 2015, 357, 1909-1918. [CrossRef] [PubMed]

82. Pesci, L.; Glueck, S.M.; Gurikov, P.; Smirnova, I.; Faber, K.; Liese, A. Biocatalytic carboxylation of phenol derivatives: Kinetics and thermodynamics of the biological Kolbe-Schmitt synthesis. FEBS J. 2015, 282, 1334-1345. [CrossRef] [PubMed]

83. Omura, H.; Wieser, M.; Nagasawa, T. Pyrrole-2-carboxylate decarboxylase from Bacillus megaterium PYR2910, an organic-acid-requiring enzyme. Eur. J. Biochem. 1998, 253, 480-484. [CrossRef] [PubMed]

84. Wieser, M.; Fujii, N.; Yoshida, T.; Nagasawa, T. Carbon dioxide fixation by reversible pyrrole-2-carboxylate decarboxylase from Bacillus megaterium PYR2910. Eur. J. Biochem. 1998, 257, 495-499. [CrossRef] [PubMed]

85. Wieser, M.; Yoshida, T.; Nagasawa, T. Carbon dioxide fixation by reversible pyrrole-2-carboxylate decarboxylase and its application. J. Mol. Catal. B Enzym. 2001, 11, 179-184. [CrossRef]

86. Miyazaki, M.; Shibue, M.; Ogino, K.; Nakamura, H.; Maeda, H. Enzymatic synthesis of pyruvic acid from acetaldehyde and carbon dioxide. Chem. Commun. 2001, 1800-1801. [CrossRef] 
87. Tong, X.; El-Zahab, B.; Zhao, X.; Liu, Y.; Wang, P. Enzymatic synthesis of L-lactic acid from carbon dioxide and ethanol with an inherent cofactor regeneration cycle. Biotechnol. Bioeng. 2011, 108, 465-469. [CrossRef] [PubMed]

88. Barzagli, F.; Mani, F.; Peruzzini, M. From greenhouse gas to feedstock: Formation of ammonium carbamate from $\mathrm{CO}_{2}$ and $\mathrm{NH}_{3}$ in organic solvents and its catalytic conversion into urea under mild conditions. Green Chem. 2011, 13, 1267-1274. [CrossRef]

89. Harnessing Nature for Low Cost, Operationally Superior, and Environmentally Friendly Carbon Capture. Available online: http:/ / www.co2solutions.com (accessed on 1 November 2016).

90. Quebec City's $\mathrm{CO}_{2}$ Solutions Posts Results from Valleyfield Demonstration Project. Available online: http:/ / www.cantechletter.com/2016/01/quebec-citys-co2-solutions-posts-results-from-valleyfielddemonstration-project/ (accessed on 1 November 2016).

91. Alvizo, O.; Nguyen, L.J.; Savile, C.K.; Bresson, J.A.; Lakhapatri, S.L.; Solis, E.O.P.; Fox, R.J.; Broering, J.M.; Benoit, M.R.; Zimmerman, S.A.; et al. Directed evolution of an ultrastable carbonic anhydrase for highly efficient carbon capture from flue gas. Proc. Natl. Acad. Sci. USA 2014, 11, 16436-16441. [CrossRef] [PubMed]

92. Lalande, J.M.; Tremblay, A. Process and a Plant for the Production of Portland Cement Clinker. Patent US6908507, 21 June 2005.

93. The Science of Climostat. Available online: http://www.climostat.co.uk/science/ (accessed on 1 November 2016).

94. Companies Turn CO2 into C3 Sugars, Adding to Biomass-Based Model. Available online: http:/ / biomassmagazine.com/articles/9581/companies-turn-co2-into-c3-sugars-adding-to-biomassbased-model (accessed on 1 November 2016).

95. Mennicken, L.; Janz, A.; Roth, S. The German R\&D program for $\mathrm{CO}_{2}$ utilization-Inovations for a green economy. Environ. Sci. Pollut. Res. Int. 2016, 23, 11386-11392. [PubMed]

96. Initiative Biotechnology 2020+. Available online: www.biotechnologie2020plus.de (accessed on 1 November 2016).

97. Gonzalez, J.M.; Fisher, S.Z. Carbonic anhydrases in industrial applications. In Carbonic Anhydrase: Mechanism, Regulation, Links to Disease, and Industrial Applications; Frost, S.C., McKenna, R., Eds.; Springer: Berlin/Heidelberg, Germany, 2014; pp. 405-426.

98. Mahon, B.P.; McKenna, R. Industrial $\mathrm{CO}_{2}$ removal using carbonic anhydrase: Potential, promise and challenges. J. Thermodyn. Catal. 2015, 6, 156-157. [CrossRef]

99. Hu, B.; Guild, C.; Suib, S.L. Thermal, electrochemical, and photochemical conversion of $\mathrm{CO}_{2}$ to fuels and value-added products. J. $\mathrm{CO}_{2}$ Util. 2013, 1, 18-27. [CrossRef]

100. Lutze, P. Distillation in bioprocessing. In Distillation-Operation and Applications; Gorak, A., Schoenmakers, H., Eds.; Elsevier: Amsterdam, The Netherlands, 2014; pp. 337-365.

(C) 2017 by the authors. Licensee MDPI, Basel, Switzerland. This article is an open access article distributed under the terms and conditions of the Creative Commons Attribution (CC BY) license (http://creativecommons.org/licenses/by/4.0/). 